\title{
EFFICACY OF GP-11 KHV DNA VACCINE IN Cyprinus carpio haematopterus
}

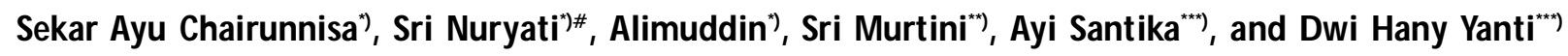 \\ *) Department of Aquaculture, Faculty of Fisheries and M arine Science, Bogor Agricultural University, Indonesia \\ ${ }^{*}$ Department of Animal Disease and Veterinary Public Health, Faculty of Veterinary M edicine, Bogor Agricultural University, \\ Indonesia \\ ***) Main Center of Freshwater Aquaculture, Sukabumi, Indonesia
}

\begin{abstract}
Koi herpesvirus (KHV) is one of the major pathogen for koi and common carp causing high mortality and economic losses for the farmers. The purpose of this study was to determine the efficacy of glycoprotein11 (GP-11) KHV DNA vaccine and compared to GP-25 KHV DNA vaccine. The vaccine in the form of naked DNA plasmid was delivered by intramuscularly injection to the three-month-old koi. The fish were divided into six groups, i.e. unvaccinated group (negative control $\mathrm{C}^{-}$and positive control $\mathrm{C}^{+}$), and vaccinated group (2.5 $\mu \mathrm{g} / 100 \mu \mathrm{L}$ of GP-11 (group 1), $7.5 \mu \mathrm{g} / 100 \mu \mathrm{L}$ of GP-11 (group 2), $12.5 \mu \mathrm{g} / 100 \mu \mathrm{L}$ of GP-11 (group 3), and $12.5 \mu \mathrm{g} / 100 \mu \mathrm{L}$ of GP-25 (group 4)). At day 42 post vaccination, all fish of each group were challenged by injecting KHV titre $10^{-3} \mathrm{FID}_{50}$. Number of dead fish was counted everyday after the challenge until 30 days. The results showed that vaccinated fish had survival rate of $83.33 \% 93.33 \%$ (group 2, 3, and 4). It showed that GP-11 KHV DNA vaccine had high efficacy. As a conclusion, the application of $7.5 \mu \mathrm{g} / 100 \mu \mathrm{L}$ of GP-11 DNA vaccines have an equal efficacy with $12.5 \mu \mathrm{g} / 100 \mu \mathrm{L}$ GP-25 related to the immune response activity against KHV infection.
\end{abstract}

\section{KEYWORDS: Cyprinus carpio koi; DNA vaccine; injection; koi herpesvirus}

\section{INTRODUCTION}

Koi herpesvirus (KHV) is considered one of the most important pathogen in koi and common carp. The virus consists of double-stranded DNA (ds) which has been assigned to the family Alloherpesviridae within the order Herpesvirales (Davison, 2010). The virions are enveloped with icosahedral capside diameter 100-110 nm with 295-kb linear ds DNA KHV genome (Aoki et al., 2007). KHV was highly virulent and naturally cause mortality for more than $80 \%$ both in koi and carp, less than a week in the subtropic area (Perelberg et al., 2003). KHV outbreaks typically occur in spring and autumn, but not when the temperatures were high as in the summer or lower as in the winter (Yuasa et al., 2008).

Various efforts have continuously been made to control the KHV diseases and one of the methods is enhancing the immune system using the DNA vaccine. DNA vaccines constitute a third generation

\footnotetext{
\# Correspondence: Department of Aquaculture, Faculty of Fisheries and Marine Science, Bogor Agricultural University, Jl. Agatis, kampus IPB Dramaga, Bogor 16680, Indonesia. Phone: + (0251) 8628755

E-mail: sri.nuryati606@gmail.com
}

vaccines after conventional, and protein recombinant vaccine. The vaccine will protect the organism against disease by injecting pure naked DNA to induce the immune response (Lorenzen \& LaPatra, 2005; Nuryati et al., 2010a). The DNA vaccine is in the form of plasmid containing a promoter and specific gene encoding a protective antigen protein of the desired pathogen (Kurath, 2008).

There are two candidate DNA vaccines for KHV that have been constructed in our laboratory, namely glycoprotein 11 (GP-11) and GP-25. GP-11 has immunogenic properties of 81 ORF KHV virus (Zhou et al., 2014). GP-11 DNA vaccine is regulated by Japanese flounder keratin promoter (Alimuddin et al., unpublished). Keratin is an active promoter in several of known tissues (Yazawa et al., 2005). The efficacy of GP-11 DNA vaccine remains to test, while GP-25 vaccine efficacy test have been conducted by Nuryati et al. (2010a). Relative percent survival of GP-25 vaccinated common carp is ranging from $60.7 \%$ to $96.67 \%$ and therefore it is considered as an effective vaccine against KHV. GP-25 is controlled by $\beta$-actin promoter of Japanese medaka fish. This study aimed to test the efficacy of GP-11 KHV DNA vaccines on koi and compared to GP-25 KHV DNA vaccine. 


\section{MATERIALS AND METHODS}

\section{Experimental Fish}

Three month old koi (Cyprinus carpio haematopterus) of $15 \mathrm{fish} / \mathrm{groups} /$ aquarium at average weight of 18-20 g were used as experimental fish. They were obtained from Main Center of Freshwater Aquaculture in Sukabumi, West Java. Screening of fish health was performed during acclimatization period and confirmed free from KHV based on polymerase chain reaction (PCR) analysis. Fish were acclimatized for two weeks in the aquarium equipped with aeration system. Fish were fed with the commercial feed ( $28 \%$ protein content) at satiation twice a day.

\section{Multiplication of GP-11 KHV DNA Vaccine}

The Escherichia coli DH5á strain that containing the GP-11 DNA plasmid was cultured in the 2xYT solid medium overnight at $37^{\circ} \mathrm{C}$. The $\mathrm{E}$. coli colonies were transferred to $2 \mathrm{XYT}$ liquid medium and incubated in incubation shaker (200 rpm) at $37^{\circ} \mathrm{C}$ for $17-20$ hours. Bacteria pellet were harvested by centrifugation for five minutes at 13,000 rpm. GP-11 plasmid was isolated using plasmid Prep Mini Spin Kit (GE Healthcare, UK) following the instructional protocol. Plasmid were resuspended with ion exchange water (IEW) and stored at $-20^{\circ} \mathrm{C}$ until it would be used for vaccination.

\section{Vaccination and Fish Maintenance Post Vaccination}

Vaccination was performed by intramuscular injection of GP-11 and GP-25 KHV DNA vaccines. The use of GP-25 KHV DNA vaccine was intended as a comparative control. The dose for the vaccination referred to Nuryati et al. (2010a) and each group was designed with triplicates (Table 1 ).

Water quality was maintained through water exchange as much as $50 \%$ per day. Fish were fed at satiation with the commercial feed contain $28 \%$ protein content twice a day. During the rearing period, water quality i.e. dissolved oxygen, $\mathrm{pH}$, and total ammonium nitrogen (TAN) were measured at the beginning, middle, and at the end of the study, whilst temperature was measured daily.

\section{Analysis of GP-11 mRNA Expression}

The analysis of mRNA expression was performed at 24 hours, 14 days, and 28 days post vaccination. Total RNA was extracted from the kidneys using RNeasy Mini Kit (Qiagen, USA). Synthesis of CDNA was carried by producing master mix (High Capacity cDNA Reverse Transcription Kit, Applied Biosystems, USA) according to number of the sample. The master mix was then added into each $200 \mu \mathrm{L}$ microtube as well as $10 \mu \mathrm{L} /$ tube, followed by RNA template insertion and then homogenized. Sample was then incubated into four steps of mRNA analysis temperature condition (step $1: 25^{\circ} \mathrm{C}$ at 10 minutes; step $2: 37^{\circ} \mathrm{C}$ at 120 minutes; step $3: 85^{\circ} \mathrm{C}$ at five minutes; dan step 4: $4^{\circ} \mathrm{C}$ at 30 second).

GP-11 mRNA expression analysis was conducted by using RT-PCR method. Primers used for PCR amplification were F-81 (F: 5'-TTA CCG GTA TGG CCT CCA CTT CAA CCG CT-3') and R-81 (R: 5'-TAG AGA TCG TCC CAG TCC TT GTT TAG-3'). The amplification process was carried out with initial temperature of $94^{\circ} \mathrm{C}$ for three minutes; $94^{\circ} \mathrm{C}$ for 30 seconds; $59^{\circ} \mathrm{C}$ for 20 seconds; $72^{\circ} \mathrm{C}$ for 30 seconds by 45 cycles; then the final extention of $72^{\circ} \mathrm{C}$ for three minutes. The PCR detection was performed by using $1.5 \%$ agarose gel electrophoresis (TopVision ${ }^{\circledR}$ Agarose, USA), and the size of amplification was predicted using 100-bp DNA ladder (Vivantis, USA).

\section{Challenge Test}

Ten percent suspension of gill from KHV-infected fish were prepared and titrated for virus isolation. Fish titration was done in koi fish. The challenged test was performed by intramuscular (IM) injection of virus suspension $0.1 \mathrm{~mL} / \mathrm{fish}\left(10^{3} \mathrm{FID}_{50}\right)$ to all groups. As a negative control, koi without vaccination was injected with PBS, while the positive control without vaccination was injected with $0.1 \mathrm{~mL}$ KHV filtrate. Each group was performed with triplicates. Challenged test was carried out on 42-day post vaccination (dpv), and observed for next 30 days on the KHV permissive temperature. The dead fish were taken and analyzed by PCR to confirm the mortality was caused by KHV infection.

\section{ELISA Test}

The serum of fish from each groups were collected on $0,7,14,21,28,35,42,56,63,70$, and $77 \mathrm{dpv}$, fish in each group were taken randomly for the preparation of blood serum. Blood serum was obtained after centrifugation at $3,500 \mathrm{rpm}, 4^{\circ} \mathrm{C}$ for 10 minutes and stored at $-20^{\circ} \mathrm{C}$ until ready to be used. The present of antibody anti-KHV were tested by indirect ELISA using KHV virus for coated plate. Antigen KHV were diluted 1:160 using a coating buffer (0:05 M carbonate-bicarbonate $\mathrm{pH}$ 9.6) to final concentration of antigen of $5 \mu \mathrm{g} / \mathrm{mL}$. The diluted-antigen was then inserted into each microplate well as much as $100 \mu \mathrm{L} /$ well and incubated at $4{ }^{\circ} \mathrm{C}$ overnight. Plate was then washed five times using $300 \mu$ L PBS-T (PBS pH $7.4+$ of $0.05 \%$ Tween-20) for each well. The plate was blocked with100 $\mu \mathrm{L} /$ well of $5 \%$ skim milk PBS solu- 
Table 1. Vaccine dosage groups

\begin{tabular}{cccc}
\hline Groups & Vaccine dosage $(\boldsymbol{\mu g} / \mathbf{1 0 0} \boldsymbol{\mu L})$ & DNA vaccine & Challenge test \\
\hline Negative control $\left(C^{-}\right)$ & - & - & Without challenge test \\
Positive control $\left(C^{+}\right)$ & - & - & Challenged \\
1 & 2.5 & GP-11 & Challenged \\
2 & 7.5 & GP-11 & Challenged \\
3 & 12.5 & GP-11 & Challenged \\
4 & 12.5 & GP-25 & Challenged \\
\hline
\end{tabular}

tion and incubated at $37^{\circ} \mathrm{C}$ for one hour. Plate was then washed with the same method as the previous step. Serum samples were diluted to $1: 100$ and then added $100 \mathrm{iL}$ to each well and incubated at $37^{\circ} \mathrm{C}$ for one hour. Plate was washed with the same method as the previous step. Anti-IgG of koi (produced by our laboratory) derived from rabbit diluted to 1:200 was added as much as $100 \mu \mathrm{L}$ in each well and incubated at $37^{\circ} \mathrm{C}$ for one hour and the plate was washed again. Anti-rabbit IgG which has been conjugated with Horse Reddish Peroxydase (HRP) diluted to 1:10,000 and then added $100 \mu \mathrm{L}$ to each well and incubated at $37^{\circ} \mathrm{C}$ for one hour. Plate was then washed with the same method as the previous step. As a substrat OneStep UItra TMB-ELISA was added $100 \mu \mathrm{L}$ to each well and let stand for 15-20 minutes. The reaction was stopped by adding $50 \mu \mathrm{L}$ of $\mathrm{H}_{2} \mathrm{SO}_{4} 2 \mathrm{M}$ and optical density (OD) was measured at $450 \mathrm{~nm}$. The cut of value (CV) in this test was obtained by the equation:

$\mathrm{CV}=$ negative control mean + standard deviation

\section{Statistical Analysis}

Survival (SR), relative percent survival (RPS), total leukocytes (TL), leukocyte differential count (DL), phagocytic activity (PA), and antibody titer were analyzed using ANOVA test with SPSS ver.19 at a significant level of 0.05 . Significant differences between groups were determined using a post-hoc Duncan test. Clinical signs, interpretation of PCR results and mRNA expression were analyzed descriptively.

\section{RESULTS}

\section{Survival}

Survival of fish after the challenge test was shown in Table 2. Survival of vaccinated fish after challenge test with KHV showed that the GP-11 $7.5 \mu \mathrm{g} / 100 \mu \mathrm{L}$ (93.33\%), GP-11 $12.5 \mu \mathrm{g} / 100 \mu \mathrm{L}$ (83.33\%), and GP-25 $12.5 \mu \mathrm{g} / 100 \mu \mathrm{L}(86.67 \%)$ were significantly higher $(\mathrm{P}<0.05)$ compared to $\mathrm{C}^{+}(33.33 \%$.

Table 2. Survival (SR) and relative percent survival (RPS) of koi challenged with KHV

\begin{tabular}{ccc}
\hline Groups & Survival rate $(\%)$ & RPS $(\%)$ \\
\hline $\mathrm{C}^{-}$ & $100.0 \pm 0.0^{\mathrm{d}}$ & - \\
$\mathrm{C}^{+}$ & $33.3 \pm 5.8^{\mathrm{a}}$ & - \\
1 & $50.0 \pm 10.0^{\mathrm{b}}$ & $24.6 \pm 15.8^{\mathrm{a}}$ \\
2 & $93.3 \pm 11.6^{\mathrm{cd}}$ & $90.5 \pm 16.5^{\mathrm{b}}$ \\
3 & $83.3 \pm 5.8^{\mathrm{c}}$ & $75.4 \pm 6.8^{\mathrm{b}}$ \\
4 & $86.7 \pm 5.8^{\mathrm{cd}}$ & $80.2 \pm 7.6^{\mathrm{b}}$ \\
\hline $\mathrm{C}^{-}=$ & unvaccinated and unchallenged fish as negative control, $\mathrm{C}^{+}=$ \\
unvaccinated and challenged with KHV as positive control, $1=$ \\
vaccinated group at dose of $2.5 \mu \mathrm{g} / 100 \mu \mathrm{L}$ of GP-11; $2=$ \\
vaccinated group at dose of $7.5 \mu \mathrm{g} / 100 \mu \mathrm{L}$ of GP-11; $3=$ \\
vaccinated group at dose of $12.5 \mu \mathrm{g} / 100 \mu \mathrm{L}$ of GP-11; $4=$ \\
vaccinated group at dose of $12.5 \mu \mathrm{g} / 100 \mu \mathrm{L}$ of GP-25. Different \\
superscript letters in the same column indicate significant \\
differences (P< 0.05$)$
\end{tabular}




\section{Clinical Signs}

Clinical signs was firstly noted in the group of $\mathrm{C}^{+}$ and group 1 (GP-11 $2.5 \mu \mathrm{g} / 100 \mu \mathrm{L}$ ) on day seven. The primary clinical signs were decreased of appetite, fish swim on the surface and difficult to breath, irregular swimming and loss of balance, hemorrhage, and necrosis in the skin and gill (Figure 1 B-D).

\section{GP Expression}

The GP-11 gene expression was detected in the kidney of all vaccinated fish with doses of $2.5 \mu \mathrm{g} / 100$ $\mu \mathrm{L}$ (1), $7.5 \mu \mathrm{g} / 100 \mu \mathrm{L}(2)$, and $12.5 \mu \mathrm{g} / 100 \mu \mathrm{L}$ (3) (Figure 2A). Meanwhile, the expression of $\beta$-actin was detected in all test samples, including control without any vaccination (Figure $2 \mathrm{~B}$ ).

\section{Phagocytic Activity (PA)}

The observations of phagocytic activity (PA) in the blood of all groups showed fluctuating results. In general, the phagocytic activity value of vaccinated fish were higher compared to control, both during the rearing period after vaccination and challenge test (Figure 3).
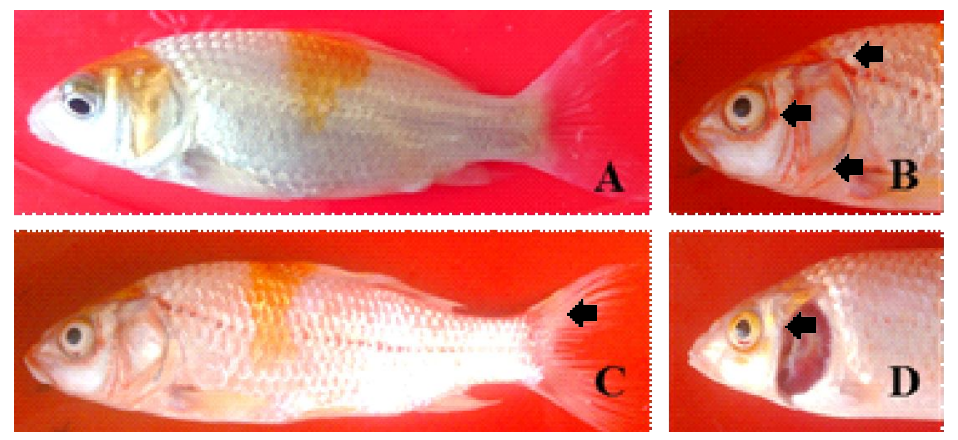

Figure 1. The clinical signs of fish infected with KHV. Healthy fish (A), hemorrhage (B), damaged fins (C), and necrosis (D)

A
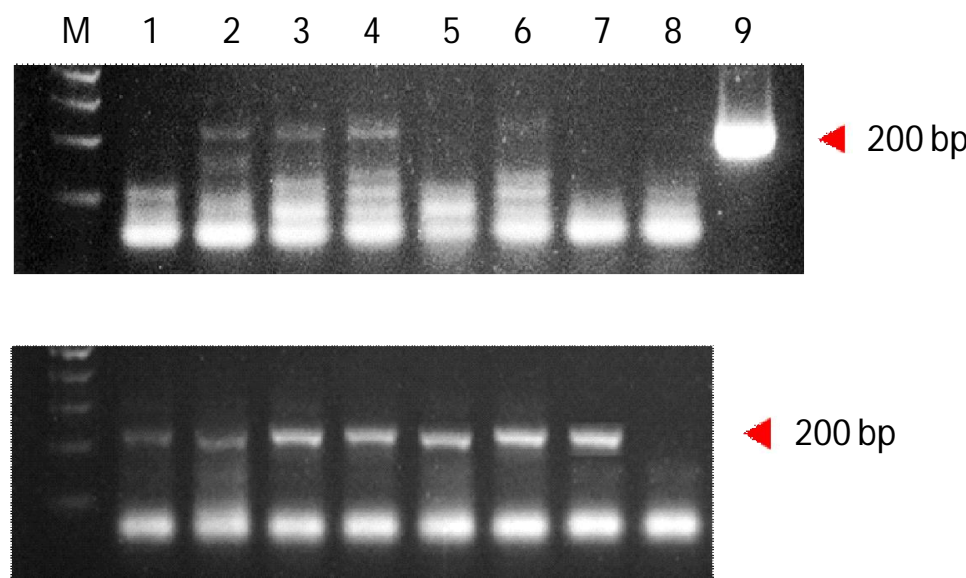

$200 \mathrm{bp}$

Figure 2. The GP-11 gene expression in the vaccinated koi (A), and PCR products by using $\beta$-actin primer (B), 100 bp DNA ladder (M), vaccine dose of $7.5 \mu \mathrm{g} / 100$ $\mu \mathrm{L}$ in $24 \mathrm{~h}$ post vaccination (1), vaccine dose of $12.5 \mu \mathrm{g} / 100 \mu \mathrm{L}$ in 24 hour post vaccination (2), vaccine dose of $2.5 \mu \mathrm{g} / 100 \mu \mathrm{L}$ in 14 day post vaccination (3), vaccine dose of $7.5 \mu \mathrm{g} / 100 \mu \mathrm{L}$ in 14 day post vaccination (4), vaccine dose of $2.5 \mu \mathrm{g} / 100 \mu \mathrm{L}$ in 28 day post vaccination (5), vaccine dose of $7.5 \mu \mathrm{g} / 100 \mu \mathrm{L}$ in 28 day post vaccination (6), control fish without vaccination (7), negative control without DNA template (8), and GP-11 plasmid as template (9). The arrows indicate the target of PCR amplification product (200 bp) 


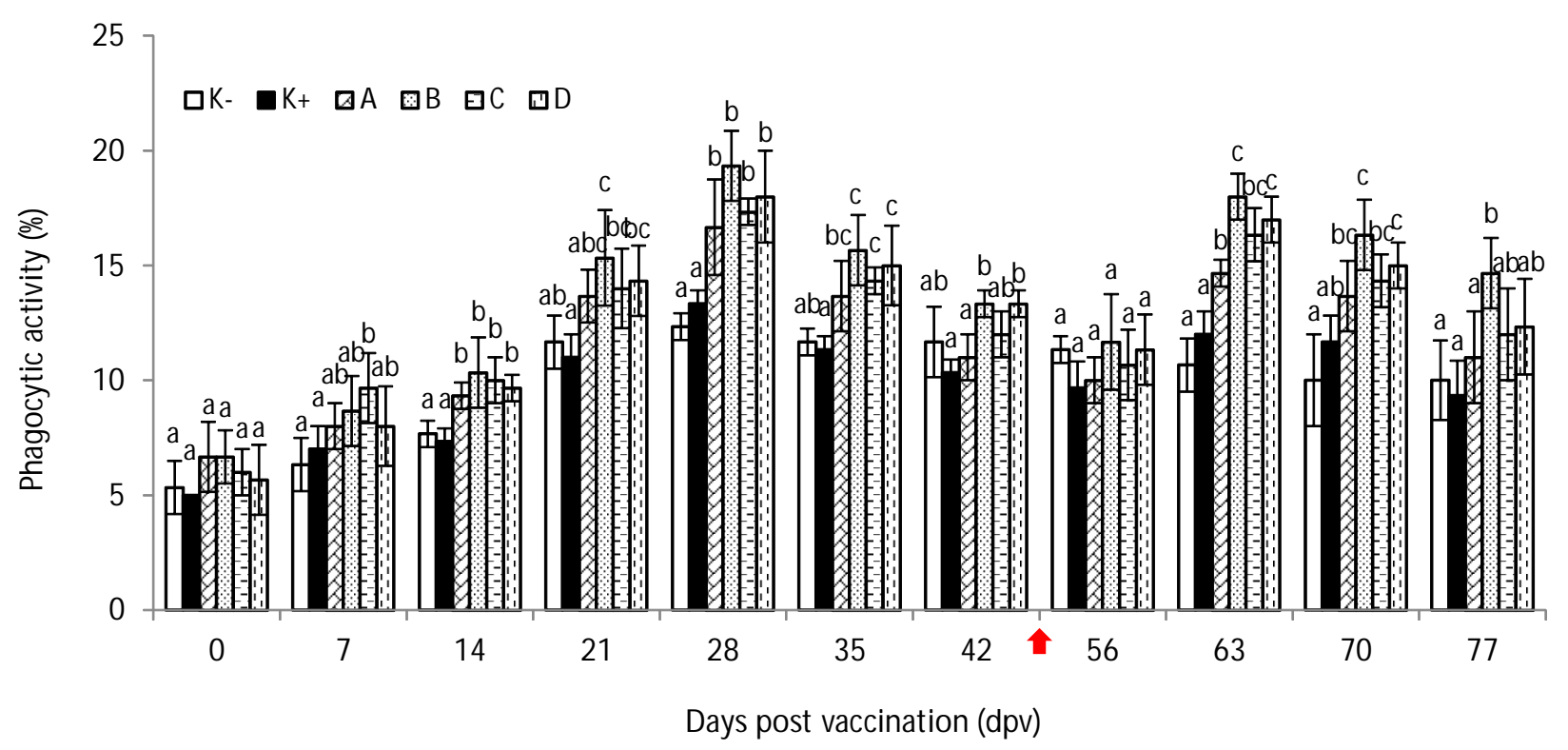

Figure 3. The phagocytic activity during the rearing period after vaccination and challenge test with KHV. The C- refer to negative control, $C^{+}$refer to positive control, GP-11 $2.5 \mu \mathrm{g} / 100 \mu \mathrm{L}$ (1), GP-11 $7.5 \mu \mathrm{g} / 100 \mu \mathrm{L}$ (2), GP-11 $12.5 \mu \mathrm{g} / 100 \mu \mathrm{L}$ (3), and GP-25 $12.5 \mu \mathrm{g} / 100 \mu \mathrm{L}$ (4). The arrow indicates the injection time for KHV challenge test

\section{Number of Leukocytes}

The number of leukocytes in this experiment were increased in all groups, started from initial day of observation until $42 \mathrm{dpv}$ and generally decreased in all groups at $7 \mathrm{dpi}(56 \mathrm{dpv}$ ) (Figure 4).

\section{Antibody Titer}

Antibody anti-KHV were able to detect on day 7 to 14 post vaccination, but on day 21 to 28 the titer was low. It showed that on day 21 to 28 the absorbance were under $\mathrm{CV}$. The antibody titer was increased

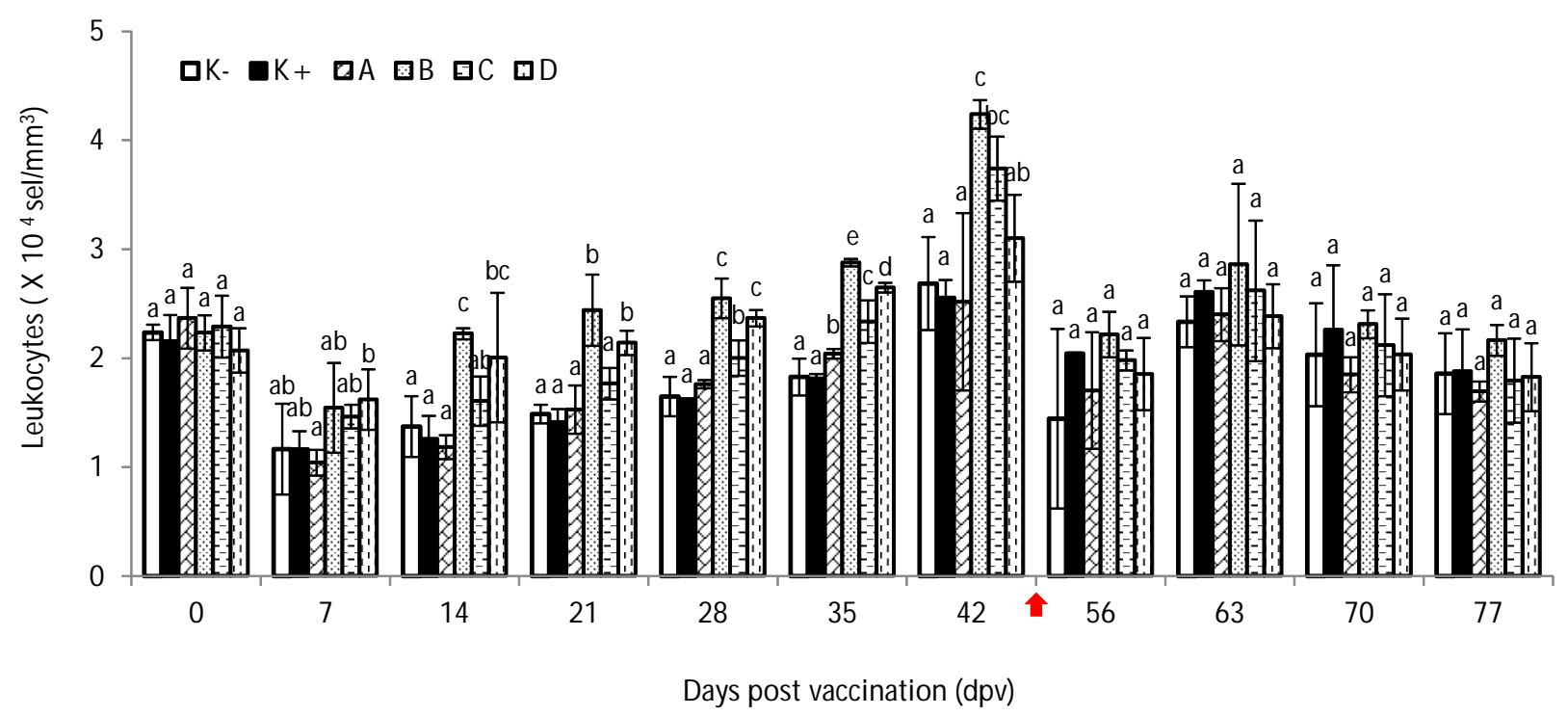

Figure 4. Leukocytes count during the rearing period after vaccination and post infection with KHV. The C- refer to negative control, $\mathrm{C}^{+}$refer to positive control, GP-11 $2.5 \mu \mathrm{g} / 100 \mu \mathrm{L}(1)$, GP-11 7.5 $\mu \mathrm{g} / 100 \mu \mathrm{L}(2), \mathrm{GP}-1112.5 \mu \mathrm{g} / 100 \mu \mathrm{L}$ (3), and GP-25 $12.5 \mu \mathrm{g} / 100 \mu \mathrm{L}$ (4). The arrow indicates the injection time for KHV challenge test 


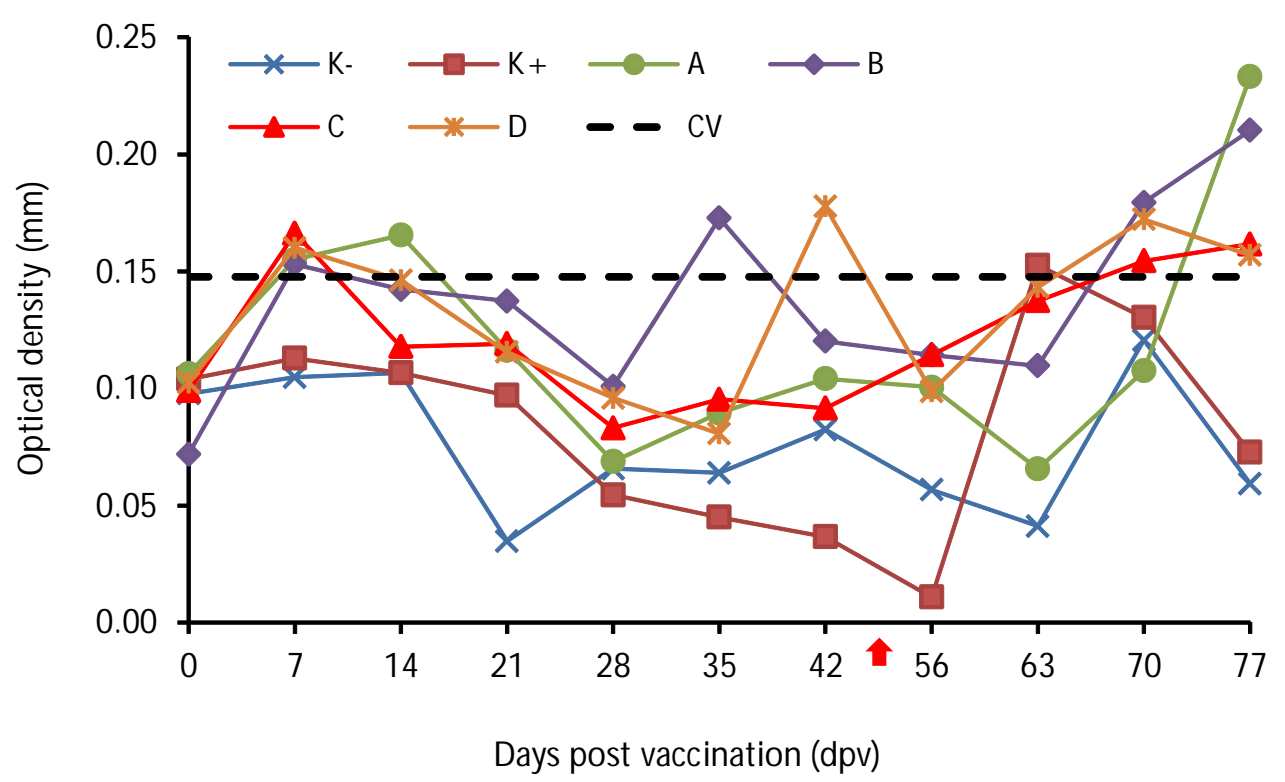

Figure 5. Titer antibodies response of koi during the rearing period after vaccination and challenge test. The $C^{-}$refer to negative control, $\mathrm{C}^{+}$refer to positive control, GP-11 $2.5 \mu \mathrm{g} / 100 \mu \mathrm{L}$ (1), GP-11 $7.5 \mu \mathrm{g} / 100 \mu \mathrm{L}(2)$, GP-11 $12.5 \mu \mathrm{g} / 100 \mu \mathrm{L}$ (3), and GP-25 $12.5 \mu \mathrm{g} / 100 \mu \mathrm{L}$ (4); the arrow indicatesthe injection time for KHV challenge test

on day 35 to 42 post vaccination and decrase again on day 56 (day 7 post infection). The antibody showed a positive value on day 70 to 77 .

\section{DISCUSSION}

High survival of vaccinated fish showed that DNA vaccines were able to be transcribed and translated into an immunogenic protein (glycoprotein KHV). The GP is recognized as the KHV antigen which able to induced specific antibody that then able to protect fish from KHV infection. This result expresses that injected DNA in the host cells will be transcribed and translated into proteins that were identical to the wild-type protein expressed by a virus that is capable of inducing immune responses as describe by Donnelly et al. (1997). RPS value in groups-2 $(90.48 \%$, $3(75.40 \%$, and $4(80.16 \%$ have met the effective range for the protection, which is more than $50 \%$ (Triyanto et al., 1997). Vaccination using lower doses, $2.5 \mathrm{mg} / 100 \mathrm{~mL}$, was unable to induce protective antibody as it shown in the higher mortality rate of about $75 \%$ after challenge test.

The use of GP-11 and GP-25 DNA vaccines in this study had the same effectiveness in relation to the protection against KHV infection. However, the lower dose of GP-11 DNA vaccine $(7.5 \mathrm{mg} / 100 \mathrm{~mL})$ was enough to provide a protection against KHV infection compared to GP-25 (12.5 g/100 mL). Therefore, in term of production cost, GP-11 DNA vaccine is more economical than GP-25.

Fish infected with KHV after the challenge test showed the prime clinical signs such as decreased of appetite, fish swim on the surface and difficult to breath, irregular swimming and loss of balance, hemorrhage and necrosis in the skin and gill. The clinical sign occurs due to the damage of epithelial cells of the skin and other cells due to the presence of KHV infection. This is consistent with the statement of Taukhid et al. (2005), that the surface of the fish's body began rough caused by the loss of mucus. This was due to the damage of epithelial cells lead to the declining of mucus production. In addition, fish also showed the rupture of blood vessels that cause bleeding (hemorrhage) (Figure 1B), damage to the fins (Figure 1C) and cell death (necrosis) in the gills (Figure 1D). Hemorrhage and necrosis in the gills cause the systemic damage to the organ (Pikarsky et al., 2004). However, some infection fish had no evidence of skin ulcer or hemorrhages (Hedrick et al., 2000). Fish showing these clinical symptoms suggest the occurrence of acute infection and generally caused mortality more than $80 \%$ both in koi and common carp in less than a week (Perelberg et al., 2003).

The transcription and translation mechanism of DNA vaccine in the host cells was proved through mRNA analysis of DNA vaccine GP-11 at 24 and 14 
hour post vaccination, respectively. The presence of GP-11 expression showed that the keratin promoter of Japanese flounder Paralichthys olivaceus could be recognized by trans-acting of koi. GP-11 gene expression in each groups could be observed in different times (Figure 2A). However, those expressions of DNA vaccines in the short-term is most likely enough to evoke an immune response both cellular and humoral immunity to provide protection against KHV infection. The immune response initiated by antigen precenting cells (APC) containing dendritic cells and macrophages that expresses the glycoprotein from the vaccine. APC containing cytosolic encoding PDNA may transcribe and translate the transgene and thereby produce immunogenic proteins, mimicking an infection of an intracellular (cytosolic) pathogen and allow presentation of the foreign antigen peptide by major histocompatibility complex (MHC) class I on the surface of the APC. Antigen presenting cells can also take up soluble antigens released from another transgene-producing cell (e.g. a myocyte), process it and present the peptide on MHC class II molecules at the cell surface. The T-cell receptor (TCR) may recognise these peptides presented on the MHC class I and MHC class II, which stimulate a CD8 + T-cell (cytotoxic T cell) and a CD4 + T-cell (helper $T$ cell) response, respectively (Tonheim et al., 2008). Cytotoxic T cells would destroyed intracellular microorganisms by identifying microorganisms presented by MHC class I on the cell surface of macrophages. Cytotoxic T cells also produce gamma-interferon which is capable of preventing the spread of microorganisms into another cell. Helper $T$ cells will recognize the microorganisms presented by MHC class II on the cell surface of macrophages. The signal induces the lymphocytes to produce various types of lymphokines. The binding of MHC class II by helper $\mathrm{T}$ cells will give a signal that B lymphocytes to proliferation into plasma cells and differentiation to make antibodies (Kresno, 2001).

Gene expression on host cell due to GP-11 DNA vaccination is strong to induce either hummoral immune response orcelluler immune response. Nonspecific immune response mechanism in this study was demonstrated by phagocytic activity value. The result showed that vaccinated groups demonstrated the higher value compared to control, either in period post vaccination or after challenge (Figure 3). Increasing of phagocytic activity was initially observed at 7 to 28 day post vaccination (dpv). Significant declines occurred in $56 \mathrm{dpv}$ (seven day postinfection), this related to the KHV challenge test process. Decreasing of phagocytic activity that observed due to cellular immune activity in the circulatory system.
Phagocytic cells was then transfered and performed it activities on the site of infection, so that the leukocytes cells that performed phagocytic activity in the blood vessels become lower (Nuryati et al., 2010a). Increasing and decreasing pattern of phagocytic activity value related to cellular immune response. Tizard (1988) stated that the increasing pattern of phagocytic activity value reflects the function of total leukocytes and it cells differentiation (lymphocytes, monocytes, neutrophils, and thrombocytes) to antigens in the body.

Other cellular immune response observed in this study was total leukocyte cells. Total leukocyte cells observed in this study showed that in all groups the value was increased until $42 \mathrm{dpv}$ (Figure 4). This condition caused by the formation of glycoprotein from GP-11 DNA injected into the body of the fish and recognized as an antigen. Fish body responded to the GP-11 glycoprotein as an antigen by increasing the production of leukocytes. The increase number of leukocytes is the response of fish immune system to develop the cellular immune response (Kresno, 2001). The number of lymphocyte during the rearing period also increased. Lymphocytes have an important role, especially in the provision of immune substances by recognizing the antigens via specific receptors on the cell membrane (Mundriyanto et al., 2002). The increase in the number of lymphocytes in these observations was inversely proportional to the number of monocytes and neutrophils that were decreased during the rearing period after the vaccination. This is more due to the absence of infection into the body so that the monocytes and neutrophils have not been fully activated. This condition was also observed in the thrombocytes during the rearing period after vaccination.

Number of leukocytes was generally decreased in all groups at $7 \mathrm{dpi}(56 \mathrm{dpv})$. Declining number of leukocytes was caused by the immune system to overcome the infection caused by KHV. The declining trend of leukocytes in the treated fish and positive control fish after challenge test were allegedly active and out from the blood vessels leading to the infected tissue (Nuryati et al., 2010b). This condition was also observed in the declining trend of lymphocytes due to the withdrawn process of lymphocytes from the circulation and competed in the infected tissue. However, the number of monocytes and neutrophils increased after the infection. Increasing number of monocytes and neutrophils cell mainly caused by KHV infection in the body so that the cells become activated. Monocytes and neutrophils were effector cells that activated by the presence of pathogen microorganisms and have a role in the inflammation at the 
early period of infection and alien destruction (Kollner et al., 2002; Clauss et al., 2008). This condition also lead to the increasing number of thrombocytes after infection. Increasing number of thrombocytes mainly due to the damaged (sores) caused by KHV infection that lead to the blood clotting to prevent further bleeding (hemorrhage) (Clauss et al., 2008).

One of the unique features of DNA vaccine is their ability to stimulate both cellular and humoral immune response (Tonheim et al., 2008). Specific antibody formed is important parameter of vaccination effect. The observations of antibody titer of all groups showed fluctuating results. Antibody titer showed a positive value at 7 to $14 \mathrm{dpv}$. However, the absorbance values at 21 to $28 \mathrm{dpv}$ were decline. The increase in the absorbance was observed again at 35 and $42 \mathrm{dpv}$, each only occur in groups 2 and 4 . This relates to the results of the GP-11 gene expression in fish body, where the GP-11 gene expression in each groups was actively observed at different times. GP11 gene expression in relation to the antibody response closely associated with promoter activity (Alimuddin et al., 2009).

Antibody titer response after the challenge test was decline at $7 \mathrm{dpi}(56 \mathrm{dpv})$. This decrease relates to the process of KHV infection, where the antibodies in the blood circulation were used to neutralize the circulating virus so that the amount of immunoglobulin $(\mathrm{lg})$ in circulation declined. However, at the end of challenge test (63-77 dpv), in the treated fish, antibody titer generally increased to $70-77 \mathrm{dpv}$. The increase in titer antibodies after the challenge test closely related to the mortality pattern, the vaccinated test fish had higher survival compared to the controls. The low mortality of vaccinated fish during the challenge associated with the ability to neutralize the KHV virus by antibodies. Neutralization is described as the loss of infectivity of the virus due to the binding of the antibodies to the virus particle (Dimmock, 1995). The neutralization mechanisms perform if there is enough antibody proportion of the infectious site, which inhibit the attachment virus to the host. Attaching the moleculs to the virus envelope could from the infected cells neutralization process. The attaching process will cause the clearance of virus by the antibody through antibody-dependent celluler cytotoxicity (ADCC) or complementdependent cytotoxicity (CDC) which inhibits virus replication within cells, virus release of the infected cells, and even virus transmission between cells (Burton, 2002).

\section{CONCLUSION}

The application of $7.5 \mu \mathrm{g} / 100 \mu \mathrm{L}$ of GP-11 DNA vaccines has an equal efficacy with $12.5 \mu \mathrm{g} / 100 \mu \mathrm{L}$ GP-25 related to the immune response activity against KHV infection. This was supported by cellular and humoral immune responses that most likely works synergically to improve the survival of vaccinated fish. Thus, GP-11 DNA vaccine was eligible to used to prevent high mortality of koi against KHV injection.

\section{ACKNOWLEDGEMENT}

I would like to express my deepest appreciation to Indonesia Endowment Fund for Education (LPDP) for the thesis scholarship and to the head of Main Center of Freshwater Aquaculture Development Sukabumi for the research facility.

\section{REFERENCES}

Alimuddin, Lola, I.P., Fahrudin, M.H.A., Chairul, M., Carman, O., \& Sumantadinata, K. (2009). $\beta$-actin promoter activity of Japanese medaka fish (Oryzias latipes) in carp (Cyprinus carpio). Jurnal Natur Indonesia, 11, 70-77.

Aoki, T., Hirono, I., Kurokawa, K., Fukuda, H., Nahary, R., Eldar, A., Davison, A.J., Waltzek, T.B., Bercovier, H., \& Hedrick, R.P. (2007). Genome sequences of three koi herpesvirus isolates representing the expanding distribution of an emerging disease threatening koi and common carp worldwide. Journal of Virology, 81, 5058-5066.

Burton, D.R. (2002). Antibodies, viruses, and vaccines. Nature Reviews, 2, 706-713.

Clauss, T.M., Dove, A.D.M., \& Arnold, J.E. (2008). Hematologic disorders of fish. Vet. Clin. Exot. Anim., 11, 445-462.

Davison, A.J. (2010). Herpesvirus systematics. Veterinary Microbiology, 143, 52-69.

Dimmock, N.J. (1995). Update on the neutralization of animal viruses. Rev. M ed. Virol., 5, 165-179.

Donnelly, J.J., Jeffrey, B.U., John, W.S., \& Margaret, A.L. (1997). DNA Vaccines. Annu. Rev. Immunol., 15, 617-648.

Hedrick, R.P., Gilad, O., Yun, S., \& Spangenberg, J.V. (2000). A herpesvirus associated with mass mortality of juvenile and adult koi, a strain of common carp. J. Aquat. Animal. Health, 12, 44-57.

Kollner, B., Wasserab, B., Kotterba, G., \& Fischer, U. (2002). Evaluation of immune functions of rainbow trout (Onchorinchus mykiss) how can environ- 
mental influences be detected?. J. Toxicology Letters, 131, 83-95.

Kresno, S.B. (2001). Immunology: Diagnosis and Laboratory Procedures, Fourth Edition (p. 341). Balai Penerbit Fakultas Kedokteran Universitas Indonesia. Jakarta.

Kurath, G. (2008). Biotechnology and DNA vaccines for aquatic animals. Revue Scientifique et Technique. International Office of Epizootics, 27(1), 175-196.

Lorenzen, N., \& LaPatra, S.E. (2005). DNA vaccines for aquacultured fish. RevueScientifique et Technique. International Office of Epizootics, 24, 201-213.

Mundriyanto, H., Taufik, P., \& Taukhid. (2002). Histological response of bullfrog (Rana catesbeiana Shaw) against bacterial infection artificially, and potency of Saccharomyces cerevisiae as immunostimulant. Jurnal Penelitian Perikanan Indonesia, 8(3), 53-63.

Nuryati, S., Alimuddin, Sukenda, Soejoedono, R.D., Santika, A., Pasaribu, F.H., \& Sumantadinata, K. (2010a). Construction of a DNA vaccine using glycoprotein gene and its expression towards increasing survival rate of KHV-Infected common carp (Cyprinus carpio). Jurnal Natur Indonesia, 13, 47-52.

Nuryati, S., Maswan, N.A., Almuddin, Sukenda, Sumantadinata, K., Pasaribu, F.H., Soejoedono, R.D., \& Santika, A. (2010b). Hematology of common carp following DNA vaccination and koi herpesvirus challenge test. Jurnal Akuakultur Indonesia, 9(1), 9-15.

Perelberg, A., Smirnov, M., Hutoran, M., Diaman, A., Bejerano, Y., \& Kotler, M. (2003). Epidemiological description of a new viral disease afflicting cultured Cyprinus carpio in Israel. Israeli Journal Aquaculture-Bamidgeh, 55, 5-12.

Pikarsky, E., Ronen, A., Abramowitz, J., Lovali-Sivan, B., Hutoran, M., Saphira, Y., Steinitz, M., Perelberg, A., Soffer, D., \& Kotler, M. (2004). Pathogenesis of acute viral disease induce in fish by carp inter- stitial nephritis and gill necrosis virus. Journal of Virology, 78(17), 9544-9551.

Rawat, M., Singh, D., Saraf, S., \& Saraf, S. (2007). An overview of biochemical aspects of DNA vaccine. Asian Journal of Biochemistry, 2(4), 208-223.

Taukhid, Sumiati, T., \& Koesharyani, I. (2005). Effect of the water temperature and total dissolved organic material toward pathogenicity of koi herpesvirus in carp (Cyprinus carpio). Serial Anthology: Management Strategy and KHV Disease Control, an solving efforts in the freshwater fish culture. Pusat Riset Perikanan Budidaya, Badan Riset Kelautan dan Perikanan, Departemen Kelautan dan Perikanan.

Tizard, I. (1988). An introduction to veterinary immunology. $2^{\text {nd }}$ edition. Wb. Philadelphia. Sanders Company.

Tonheim, T.C., BØgwald, J., \& Dalmo, R.A. (2008). What happens to the DNA vaccine in fish? A review of current knowledge. Fish \& Shellfish Immunology, 25, 1-18.

Triyanto, Kamiso, H.N., Isnansetyo, A., \& Murwantoko. (1997). Contruction of pure antigen to produce antibody and vaccine polyvalent of Aeromonas hydrophilla. Laporan penelitian hibah bersaing $V / 1$ perguruan tinggi tahun anggaran 1996/1997. Fakultas Pertanian UGM. Yogyakarta.

Yazawa, R., Hirono, I., \& Aoki, T. (2005). Characterization of promoter activities of four different Japanese flounder promoters in transgenic zebrafish. Marine Biotechnology, 7, 625-633.

Yuasa, K., Ito, T., \& Sano, M. (2008). Effect of water temperature on mortality and virus shedding in carp experimentally infected with koi herpesvirus. Fish Pathol., 43, 83-85.

Zhou, J., Xue, J., Wang, Q., Zhu, X., Li, X., Lv, W., \& Zhang, D. (2014). Vaccination of pasmid DNA ORF 81 gene of CJ strains of KHV provides protections to immunized carp. In Vitro Cell DevBiol-Animal, 50, 489-495. 